\title{
The Effect of Stad Type Cooperative Learning Initiated by Story Questions toward the Ability to Complete Story Questions in Math of Class viii Students of Junior High School (SMPN 1 and MTSN) in Pangean District, Kuantan Singingi Regency
}

\author{
Zulkarnain \\ Faculty of Education, University of Riau, Pekanbaru, Indonesia, Correspondence: Zulkarnain, \\ Faculty of Education, University of Riau, Pekanbaru, Indonesia \\ Email: Stoper65@yahoo.com
}

\author{
Doi:10.5901/mjss.2015.v6n3s1p102
}

Abstract

Giving students story questions is one of the efforts to achieve the goal of learning in Mathematics which is formal and material. One of the key aims of teaching and learningMath in schools is to develop the students' ability to complete story questions for they can improve students' ability in solving problems. In fact, Math is one of the lessons that the students don't like much which could affect their learning achievement and their ability in completing story questions. Therefore, research needed to be conducted to improve the student's ability to complete story questions. This research aimed to find out (1) the effect of STAD type cooperative learning initiated using story questions in Math toward the students' ability in completing the story questions of Class VIII students of Junior High School (SMPN and MTsN) in Pangean district Kuansing Regency in the academic year $2013 / 2014$, (2) to compare the ability of SMPN and MTsN students in completing story questions in Math after being taught through the STAD type cooperative learning initiated by story questions. Quasi-experimental design was employed in this study using the One Group Pre-test-Post-test Design that is part of the Quasi-Experimental Design Without Control Group whereby 19 students of SMPN and 26 students of MTsN were taken as the sample of the study. This design is chosen because the researcher wants to observe the students' capabilities in solving story questions before and after treatment. The data were collected by administering an achievement test. The findings of the study showed that there was an effect of applying the STAD type cooperative learning initiated by giving the students story questions toward the improvement of their ability in completing the story questions, that is, $44,74 \%$ and $82,57 \%$. In addition, there was also a difference in the average score of the students' achievement in Math of both schools where the average score of Class VIII students of MTsN was better than that of the average score of SMPN students.

Keywords: Effect, story questions, STAD type cooperative learning, ability, completion

\section{Introduction}

Students' learning achievement in Math could be seen from their ability in completing mathematical questions that consist of non-story questions and story questions. Story questions are questions given in the form of stories related to the students' life situation. As stated in the 2006/KTSP curriculum that one of the goals of learning Math in primary education is to prepare students to be able to face changes in their lives that are developing through exercises on the basis of logical thinking that is analytical, systematic, creative, accurate, honest, effective as well as providing them with collaborative ability. Therefore, students should be given questions related to their daily lives which are more known as story questions.

Giving students story questions is an effort to achieve the goal of learning Math that is formal and material. According to Marpaung (2004) the goals of teaching Math at schools are broken into formal and material goals. The first one refers to (1) restructuring the students' reasoning and (2) developing individual attitude while the latter refers to (1) the mastery of mathematical materials and (2) the use and the application of Math and (3) skills. Among those goals, the formal aspect is more focused on the structuring of reasoning reflected in the steps of completing story questions, whereas the material aspect emphasizes more on the skills of completing the questions or solving problems including the use of Math in the form of stories related to their own daily lives.

Developing student's ability in completing story questions could improve their ability in solving their problems. The 2006 curriculum states that students need to develop their ability in solving problem so that they are able to resolve mathematical problems properly and at the same time they can develop their creativity. However, the teaching and learning process that can guide and train students to be able to resolve problems is still in question. Various findings in 
the fields have indicated that there are still weaknesses in the process of teaching and learning in Math because that process seems to have not prepared the students to solve the problems. These problems are among others, (1) the teaching and learning process in Math is limited to making the students able to complete questions in tests (Armanto, 2002) that are constructed in the form of multiple choice where the students tend to learn Math by memorizing examples of test items with answer keys available. (2) Students learning Math are separable from their own daily lives, (3) teachers teach by using conventional methods (Zulkardi, 2005).

In addition, students have disliked Math since they were at primary schools so that their learning achievement is low (Soejdadi 2001; Pejabat Wilayah Departemen Pendidikan Nasional Riau 2004). Furthermore, Supartono (2006) argues that there are, in fact, a great number of students who have difficulties in learning Math because it is not relevant with their daily lives; the teaching methods employed are monotonous, going from abstract to concrete. According to Rohani (2005) students learn Math without realizing its benefits, while Zulkardi (2007) thinks there are big problems in Mathematics Education in Indonesia, that is; student's achievement in solving problems related to their daily lives still remains low. Besides, the average score of their national exam in Math in 2005 (primary education) was about 5.13 and from five sub-themes of their national exam questions they could only achieve the average score of 5.03 .

Meanwhile, based on the writer's observations towards elementary school students, junior and senior high school students and even university students, it was identified that students were unable to complete story questions. They were only able to complete the questions if the questions were in the form of stories. The test results of the Third International Mathematics and Science Study (TIMSS) in 2003 proved that Indonesian students' mastery was ranked thirty eight of forty countries. One of the reasons was that most of the question items were related to contexts or the students' daily lives (Zulkardi,2007). This happened because the evaluation system was not appropriate and the students were not taught how to deal with story questions which also caused them to have difficulties in learning Maths in Economics, Physics and Chemistry subjects.

There are the many factors that caused students to be unable to complete the story questions which bring about their low achievement, among others, the teaching and learning process. It seemed that using conventional teaching strategies was not effective to encourage the students to solve mathematical problems as they were only receive the teacher's explanation; they are not encouraged to solve problems (Zulkardi, 2005). In fact, in conventional methods the teacher's role is more dominant while the students are passive. The teacher tends to only transfer the knowledge; therefore, this strategy should be changed by attracting the students' creativity that can improve their learning achievement.

To provide the students with basic ability requires the schools and teachers to manage the teaching and learning process properly. Teachers in particular need to change their teaching techniques that could encourage the students to be more active and innovative so that the teaching and learning process suits the recent development of human resources. Such strategies attempt to create students to be more creative, independent, and able to solve problems.

Mathematics is a knowledge that trains the mind, solves problems and makes decisions, so that by this moment the usage of learning mathematics is very observed in everyday life (Noraini 2001). Furthermore, Noraini explains the reformation that happened within the education of mathematics, as follows: first, students learn to appreciate the value of mathematics; mathematics is introduced to the students to be practiced in everyday life. For example: the volume of a cube can be associated with the volume of the tub. Second, student will be confident with their own capabilities. Students are involved within an active process so that they will be able to solve problems and understood the subject so that they will have confidence within themselves. Third, students learned to communicate in mathematics. Students are introduced to the adeptness of communication through story questions. Fourth, students are capable in solving problems. Students are faced with a challenging problem solving, like able to interpret a problem, devise and arrange a strategy and procedure in solving a mathematics problem. Fifth, students learn to think mathematically; teachers need to explain to students to do a mathematics problem solving carefully, clearly and structured. This can be attempted by changing the paradigm of teachers by giving the students understanding that mathematics is very much needed in their daily lives. The learning that can be done in this, one of them is contextual learning.

According to Sanjaya (2007), contextual learning emphasizes on the process of involving students completely to be able to find the materials to be learned and connect them with real life situations. Johnson (2008) expresses that contextual learning, as a sort of system that teaches based on the notion that the meaning came from the relation between the content and its context. Context gave meaning to the content. The more connections discovered by students in a certain wide context, the more meaningful the content will be for them. Within that process students examine and adjust the new knowledge that was learned with the knowledge or thinking structure that they already have. Meanwhile, Nur (2000) stated that contextual learning emphasizes on context as the first steps of learning, in exchange of introducing concept in an abstract way. In contextual learning, the process of developing concepts and mathematical ideas starts 
from the real world. Real world does not only mean concrete physically or visibly, but also including matters that can be imagined by the realm of thought of the students because it corresponds with their experience. This means that the problems that were used in the beginning of the mathematics education that was contextual can be problems that really exist within the students' lives or problems that the students can imagine as being real.

One of the objectives of contextual mathematical education is so that the math subject won't be viewed as merely something to be delivered to students. However, the expectation is that mathematical education needs to be viewed as an activity which is called mathematical process. Suryanto (2001) formulize that the mathematical process that should happen within the mathematical education has two forms which are horizontal mathematical process and vertical mathematical process. Horizontal mathematical process is the appearance (suggested, found) of the way or mathematical tool or mathematical model by the students from their efforts to solve a mathematical problem which relates to their daily lives. Vertical mathematical process is the process of reorganizing the way or mathematical tool or mathematical model that has appeared (suggested, found) by the students during the horizontal mathematical process into the formal mathematical system. According to Suryanto (2001), horizontal mathematical process is translated as the movement from the real world to the symbolic world, while the vertical mathematical process is the movement or process that happens within the symbolic world itself. When a mathematical learning is managed by directly discussing about abstract mathematical symbols without at first relating the meanings of it into the real world or the realm of thought that the students have that are relevant, that means the teaching and learning activity will only cover the abstract form of vertical mathematical process.

One of the strategies of contextual learning within the mathematical education is a learning that begins with giving story questions that has something to do with the learning materials that will be discussed. The giving of story questions aims to make the students feel the benefit of math in their daily lives, so that the students will be more willingly and interested with the learning. Next, the teacher along with the student will solve the problem using the steps of solving story questions, which are deciding the things that was discovered within the problem, deciding the things that was questioned within the problem, creating the mathematical model, doing some calculations and determine the final solution according to what the problem demanded. With the method of giving tasks, the teacher guides the students to follow the steps as follows. At the step of creating mathematical model and before doing calculations, the teacher explains about concept, principles and operations needed to solve the problems given (Zulkarnain 2000). In conventional learning, the explanation of concept is done by teachers in the beginning of learning. Next, according to Zulkarnain (2000) learning like this has several advantages, like: 1) Able to motivate students in learning. This is because the developing of concepts and ideas of mathematics began from the real world, so that students know the purpose of the material that will be learned. 2) Able to shorten time. Usually learning about story questions are placed by the end of a material, so that by giving the story question in the beginning of a learning session will give the impression of not needing the extra time just to learn about the story question. 3) Generally the materials of mathematics in school can be made in a narrative form, so that the deliverance of story questions at the beginning of the session will make the students get used to its forms. The impact from the students getting used to solve story questions is that students no longer feel intimidated when given story questions.

Aside from choosing strategies, teachers can also choose learning methods that are expected to attract the students' willingness to learn, which is by placing students in groups. One of the learning methods in groups that could realize such notion is cooperative learning.

Kauchak and Eggen (1993) defined that cooperative learning is a collection of learning strategies that are utilized by students to help one another inside the group in learning something. Furthermore, they define that cooperative learning is a collection of learning strategies that involves students to learn together inside small groups to achieve certain purposes. Cooperative learning nourishes the forming of working groups in a positive environment, to deny any form of individual rivalry and academic environment isolation. Slavin (2010) stated that students will discover more and understand difficult concepts when they discuss such issues with their friends.

Slavin (2010) expresses that there are three main concepts that became cooperative learning characteristics, which are group appreciation, individual responsibility and the same chances to succeed. Meanwhile, Ibrahim (2000) expresses that there are 4 types from cooperative learning, which are: (a) students work in groups cooperatively to finish their learning material, (b) groups are formed from students that has high, medium and low capabilities, (c) if possible, group members are consisted from different race, culture, type and gender, (d) appreciation is oriented more in a group than individually.

Ibrahim (2000) stated that cooperative learning is consisted of six phases. Also the six phases are presented in Table 1 below: 
Table 1: Phases of Cooperative Learning Model

\begin{tabular}{|c|c|c|}
\hline No. & Phase & Teacher's Attitude \\
\hline 1. & $\begin{array}{l}\text { Delivering objectives and } \\
\text { motivates students }\end{array}$ & $\begin{array}{l}\text { Teacher delivers all the learning objective that needs to be achieved in the session and } \\
\text { motivates the students to learn }\end{array}$ \\
\hline 2. & Serving information & Teacher serves informtion to students by way of demonstration or through reading materials \\
\hline 3. & $\begin{array}{l}\text { Organizing students in learning } \\
\text { groups }\end{array}$ & $\begin{array}{l}\text { Teacher explains to students how to form learning groups and help each and every groups to } \\
\text { do transitions efficiently }\end{array}$ \\
\hline 4. & $\begin{array}{l}\text { Guide groups in working and } \\
\text { learning }\end{array}$ & Teacher guides learning groups when they are doing their exercises \\
\hline 5. & Evaluation & $\begin{array}{l}\text { Teacher evaluates their learning results about the materials that has been studied or each } \\
\text { groups presents their own work results }\end{array}$ \\
\hline 6. & Giving appreciations & $\begin{array}{l}\text { Teacher gives out appreciations from the results that has been obtained from groups and } \\
\text { individuals }\end{array}$ \\
\hline
\end{tabular}

(Ibrahim, 2000)

One of the types of cooperative learning is STAD type (Student Team Achievement Division). According to Slavin this type of learning model has some important characteristics; that is, group respect, responsibility, and opportunity to get success. In addition, Slavin states that this learning model has some advantages, among others, (1) students get the knowledge and develop it through interactions with other people, (2) the evaluation system in the teaching and learning process can arouse the students' motivation to perform much better for themselves and for their colleagues so that collaboration is sustainable.

On the other hand, Heleni (2000) argues that the teaching and learning process that begins by giving students story questions causes difficulties for them to complete the story questions especially when they are changing verbal sentences into mathematical models. As a result, the results of counting and the answers to the story questions are wrong. This was based on the research she conducted on students completing story questions individually. In view of the previous explanations, it is clear that giving students story questions is important although weaknesses are still found in this kind of teaching and learning process. Through story questions students practice applying Math in their daily lives and in other subjects. It seemed that in her research the researcher wanted to cover junior high school students' weaknesses in completing the story questions individually by using STAD type cooperative group. That is the reason why there is a need to conduct research to improve the students' ability in completing story questions.

\section{Formulation of the Problem}

The problem of the research is formulated in the following research questions:

(1) Is there any effect of STAD type cooperative learning initiated by giving story questions towards the ability in completing story questions of the students of State Junior High School (SMPN 1) Class VIII Pangean District, Regency of Kuansing in the academic year 2013/2014?

(2) Is there any effect of STAD type cooperative learning initiated by giving story questions towards the ability in completing story questions of the students of State Religious Junior High School (MTsN) Class VIII Pangean District, Regency of Kuansing in the academic year 2013/2014?

(3) Is there any difference in the ability to complete story questions in Math between Class VIII students of SMPN 1 and M.TsN Pangean District, Regency of Kuansing in the academic year 2013/2014 after being taught using STAD type cooperative learning initiated with story questions?

\section{Research Hypothesis}

(1) There is a significant effect of STAD type cooperative learning initiated by giving story questions towards the ability in completing story questions of the students of SMPN 1 Class VIII Pangean District, Regency of Kuansing in the academic year 2013/2014.

(2) There is a significant effect of STAD type cooperative learning initiated by giving story questions towards the ability in completing story questions of the students of M.Ts Class VIII Pangean District, Regency of Kuansing in the academic year 2013/2014.

(3) There is a significant difference in the ability to complete story questions in Math between Class VIII students of SMP and M.Ts Pangean District, Regency of Kuansing in the academic year 2013/2014 after being taught 
using STAD type cooperative learning initiated with story questions.

\section{Research Methodology}

This research is quasi-experiment. According to Sugiyono (2010) quasi-experiment research is a research method used to find out the effect of a certain treatment towards the other in a controlled condition. The design of the experiment embraced the Single Group Pre-test/Post-test Design (Jackson, 2003) which belongs to Quasi Experimental Design Without Control Group. The research design is described as follows:

$\mathrm{O}_{1} \mathrm{XO}_{2}$

This design involved an experimental group of every school that would get the treatment of STAD type cooperative learning initiated by giving story questions $(X)$. This design is chosen because the researcher wants to observe the students' capabilities in solving story questions before and after treatment. $\mathrm{O}_{1}$ was the result of the pre-test given to the sample on the material that had been learned in the form of mathematical story questions, whereas $\mathrm{O}_{2}$ was the result of the post-test given to the sample on the learning material after the treatment in the form of story questions in Math.

The STAD type cooperative learning was practiced by the teachers of Junior High School (SMP No. 1) in Pangean district where the research was carried out. These teachers were first trained how to employ this teaching strategy. The training was held from 15th November until $2^{\text {nd }}$ December 2013. The sample of the research were students of Class VIII-2 of the odd semester SMPN 1 Pangean totalling 19 students and the students of Class VIII-1 M.TsN Pangean totalling 26 students in the academic year 2013/2014 using simple random sampling. The data were collected using observations and tests. The data gained from observations were analysed descriptively and the ones obtained through achievement tests were analysed using inferential statistic analysis, whereas data gained from students' learning achievement were analysed using t-test $\alpha=0.05$.

\section{Research Findings}

The data of students' learning achievement were processed by analysing their learning achievement in Math through a pre-test and a post-test. These results were analysed to test the research hypotheses.

\subsection{Data of Pair Observation Test of SMPN 1}

This test was administered in order to test the hypothesis. The result was that there was a significant effect of STAD type cooperative learning initiated by giving story questions towards the students' ability in completing the storey questionsin Math of the students of Class VIII SMPN 1 Pangean district Kuantan Singigi regency in the academic year 2013/2014. Based on the data analysis it was discovered that the students' average score after the treatment was better than before the treatment. To know to what extent the effect of the STAD type cooperative learning initiated by giving story questions towards the student's learning achievement, an additional test was administered and the result showed that the $r^{2}$ was 0,4474 with the co-efficient effect or $K_{P}$ of $44,74 \%$. In other words, the effect of the STAD type cooperative learning initiated by giving story questions towards the ability of Class VIII students of SMPN 1 Pangean Kuantan Singingi to complete the story questions in the academic year 2013/2014 was 44, $74 \%$.

\subsection{Data of Pair Observation Test of M.TsN1}

This test was administered in order to test the hypothesis. The result was that there was a significant effect of STAD type cooperative learning initiated by giving story questions towards the students' ability in completing the story questions in Math of the students of Class VIII M.TsN 1 Pangean district Kuantan Singingi regency in the academic year 2013/2014. Based on the data analysis it was discovered that the students' average score after the treatment was better than before the treatment. To know to what extent the effect of the STAD type cooperative learning initiated by giving story questions towards the student's learning achievement, an additional test was administered and the result showed that the $r^{2}$ was $0,82,57 \%$ with the co-efficient effect or $\mathrm{K}_{\mathrm{P}}$ of $82,57 \%$. In other words, the effect of the STAD type cooperative learning initiated by giving story questions towards the ability of Class VIII students of M.TsN1 Pangean Kuantan Singingi to complete the story questions in the academic year 2013/2014 was 82, $57 \%$. 


\subsection{Data of Independent Observation Test of SMPN 1 and M.TsN 1}

The pair observation test was administered to test the hypothesis. The result showed that there was a difference between the ability of SMPN 1 students and M.TsN students in Pangean district Kuantan Singingi regency in completing the story questions in the academic year 2013/2014 after the STAD type cooperative learning was employed. Based on the data analysis it was proven that the average mean scores of the two schools were different. In fact, the average score of M.TsN 1 students was better than that of SMPN1.

\section{Discussion on Research Findings}

The data analysis using the t-test provided the evidence that the students' ability in completing the story questions in the post-test was better than in the pre-test. It means that the students' ability became better after they were taught using the STAD type cooperative learning initiated by giving them story questions at SMPN1 and M.TSN 1 Pangean district Kuantan Singingi regency.

The findings of this study support the findings of some previous contextual research such as Jatnika's (2007) whose research findings identified that contextual teaching and learning (CTL) could improve the students' learning achievement in Math. Furthermore, Darhim (2004), Harliani (2005) and Mulyati (2009) also proved that there was a significant difference in learning achievement between the students who were taught using CTL than those who were taught using conventional strategies. In addition, this research supports some previous studies where students' learning achievement was improving after the cooperative learning strategy was applied (Emmar \& Gerwels, 2002).

Despite the benefits of the STAD type cooperative learning initiated by giving students story questions, mistakes were still found in the students' daily exercises that could be seen in Table 2 and Table 3.

Table 2. The Frequency of Class VIII Students' Ability of SMPN Pangean in Completing Story Questions on SPLMaterials

\begin{tabular}{lccccccccc}
\hline \multirow{2}{*}{ The steps of completing story questions } & \multicolumn{1}{c}{$\begin{array}{c}\text { Number of questions } \\
\end{array}$} & $\mathrm{F}$ & $\%$ & $\mathrm{~F}$ & $\%$ & $\mathrm{~F}$ & $\%$ & $\mathrm{~F}$ & $\%$ \\
\hline Identifying what is known & 19 & 100 & 19 & 100 & 19 & 100 & 19 & 100 \\
Identifying what is asked & 19 & 100 & 19 & 100 & 19 & 100 & 19 & 100 \\
Making mathematical model & 16 & 68.18 & 25 & 56.82 & 25 & 56.82 & 28 & 63.64 \\
Completing the operation & 10 & 52.63 & 11 & 57.89 & 9 & 47.37 & 7 & 36.84 \\
Deciding the final answer & 10 & 52.63 & 11 & 57.89 & 9 & 47.37 & 7 & 36.84 \\
\hline
\end{tabular}

$\mathrm{F}:$ Frequency

Table 3. The Frequency of Class VIII Students' Ability of M.TsN Pangean in Completing Story Questions on SPL Materials

\begin{tabular}{|c|c|c|c|c|c|c|c|c|}
\hline \multirow{3}{*}{ The steps of completing story questions } & \multicolumn{8}{|c|}{ Number of questions } \\
\hline & \multicolumn{2}{|c|}{1} & \multicolumn{2}{|c|}{2} & \multicolumn{2}{|c|}{3} & \multicolumn{2}{|c|}{4} \\
\hline & $\mathrm{F}$ & $\%$ & $\mathrm{~F}$ & $\%$ & $\mathrm{~F}$ & $\%$ & $\mathrm{~F}$ & $\%$ \\
\hline Identifying what is known & 26 & 100 & 26 & 100 & 26 & 100 & 26 & 100 \\
\hline Identifying what is asked & 26 & 100 & 26 & 100 & 26 & 100 & 26 & 100 \\
\hline Making mathematical model & 26 & 100 & 25 & 96.15 & 25 & 96.15 & 15 & 57.69 \\
\hline Completing the operation & 18 & 69.32 & 24 & 92.31 & 23 & 88.46 & 12 & 46.15 \\
\hline Deciding the final answer & 18 & 69.23 & 24 & 92.31 & 23 & 88.46 & 12 & 46.15 \\
\hline
\end{tabular}

Based on the observation of the students' answer keys of their daily exercises especially the completion of the SPL story questions using the graph method, in general the students did not yet master the concept of identifying the intersection point so that the graph was wrong in its completion. They were unable to correctly identify the intersection point at the $X$ and $Y$ coordinates of each equation and they made a mistake at the Cartesius coordinates as a result, they made a mistake when identifying intersection point. This happened because the teacher did not ask the students to draw graphs on a graph paper so that many of them could not identify the intersection point when completing the drawing.

In addition to using the graph method the students also use a mixed method to complete the SPL. The students' 
mistakes mostly stemmed from constructing the equation into the equivalent equation with the initial equation. In other words, they students were unable to identify the multiplication number for each equation so that one of the variables could be eliminated. Also, the students were not accurate in the mathematical counting operation.

In view of the above circumstances, giving students compliments in each meeting and their daily exercise will encourage to them be more motivated in learning so that they can have good achievement for their groups. This idea is in line with the research finding proving that students would make better achievement when they are motivated and given compliments (Slavin, 2010).

\section{Conclusions and Suggestions}

\subsection{Conclusions}

On the basis of the research findings and discussion in the previous chapter some conclusions are drawns as follows:

(1) There is a significant effect of STAD type cooperative learning initiated by giving story questions towards the ability in completing story questions of the students of SMPN 1 Class VIII Pangean district, regency of Kuansing in the academic year 2013/2014 (44,74\%).

(2) There is a significant effect of STAD type cooperative learning initiated by giving story questions towards the ability in completing story questions of the students of M.Ts Class VIII Pangean District, Regency of Kuansing in the academic year 2013/2014 (82,57\%).

(3) There is a significant difference in the ability to complete story questions in Math between Class VIII students of SMP and M.Ts Pangean District, Regency of Kuansing in the academic year 2013/2014 after being taught using STAD type cooperative learning initiated with story questions. The average score of Class VIII of M.TsN students is better than that of Class VIII of SMPN 1 students in Pangean district, Kuansing regency.

\subsection{Suggestions}

The following suggestions are given on the basis of the researcher's experience the conduct of the research:

1. The STAD type Cooperative Learning initiated with giving students story questions could be one of the alternatives of innovative learning that could encourage the students to complete story questions in Math and in return could improve the students' learning achievement. For this reason, it is suggested that this learning model should be applied in teaching Math.

2. Due to limited funding, this research could only be carried out in a small region. Therefore, to those who intend to carry out researches in a similar area in the future, it would be best if it is done in a wider coverage.

\section{References}

Armanto, Dian. 2002. Teaching Multiplication and Division Realistically in Indonesian Primary School: A Prototype of Local Instructional Theory. Disertasion.Enschede: Print Partners Ipskamp5

Darhim.2004. Pengaruh Pembelajaran Kontekstual Terhadap Hasil Belajar dan Sikap Siswa SD Kelas Awal Dalam Matematika. Disertasi, tidak diterbitkan. Bandung: PPS UPI.

Dinas Pendidikan Provinsi Riau. 2004. Data dan Informasi Pendidikan Provinsi Riau tahun 2003. Pekanbaru

Direktorat Jenderal Pendidikan Dasar. 2006. Kurikulum Tingkat Satuan Pendidikan. Depdiknas : Jakarta.

Eggen, D. Paul, Kauchak and P. Donald, 1993, Strategies For Teachers, Teaching Contens and Thinking Skill. Allyn and Bacon Publishers, Boston

Emmer.D.\& Gerwels,M. 2002. Cooperative learning in elementary classrooms: Teaching in practices and lessons characteristics. The Elementary School Journal, 103,75-91

Harliani, Dwi. 2005. Pengaruh Pendekatakan kontekstual dalam Pembelajaran Matematika terhadap Motivasi dan Hasil Belajar Matematika Siswa di Kelas V SD Blambangan Bojonegoro. Laporan Penelitian: FMIPA UNESA

Heleni, Susda.2000. Pembelajaran Yang Dimulai Dengan Pemberian Soal Cerita Untuk Meningkatkan Hasil belajar Matematika Siswa Kelas II SMPN Banuhampu Sungai Puar. Laporan Penelitian. Padang: Lemlit UNP.

Ibrahim, Muslim., 2000, Pembelajaran Kooperatif, Unesa-University Press, Surabaya.

Jackson, Sherri L. 2003. Research Methodes and Statistics. Singapore: Thomson Learning.

Jatnika, Trimulya. 2007. Pembelajaran Matematik Melalui Pendekatan Kontekstual di Kelas IV SDN Cipetir Jawa Barat.digilib.upi.edul pasca/available/etd-1222106-111445/

Johnson, Elaine. B. 2008. Contextual Teaching and Learning: Menjadikan Kegiatan Belajar Mengajar Mengasyikandan Bermakna. Bandung: MLC. 
Marpaung, Yansen. 2004. Mengejar Ketertinggalan Kita dalam Pendidikan Matematika. Unesapress: Surabaya.

Mulyati, Sri. 2009. Pengaruh Pendekatan Kontekstual Dalam Proses Belajar Mengajar Matematika Terhadap Sikap, Motivasi, dan Hasil Belajar Siswa Kelas VII SMP Labor UM. Karya-ilmiah.um.ac.id/index.php/disertasi/article/view/985.

Noraini Idris. 2001. Pedagogi Dalam Pendidikan Matematik. Cheras, Kuala Lumpur: CetakCepat. SDN BHD.

Nur, Muhammad. 2000. Realistic Mathematics Education. Makalah dalam seminar Tentang Contextual Learning Dalam Pendidikan Matematik di Unesa Surabaya.

Rohani, Ahmad. 2005. Pengelolaan Pengajaran. Edisi Revisi. Rineka Cipta: Jakarta.

Sanjaya, Wina. 2007. Strategi Pembelajaran Berorientasi Standar Proses pendidikan. Jakarta: Kencana.

Slavin, R. E., 2010, Cooperatif Learning Theori Researh and Practice, Terjemahan NarulitaYusron, Nusa Media, Bandung.

Soedjadi, R. 2001. Nilai-Nilai dalam Pendidikan Matematika dan Upaya Pembinaan Pribadi Anak Didik. Unesa: Surabaya

Sugiyono., 2010, Metode Penelitian Pendidikan Pendekatan Kuantitatif, Kualitatif, dan R \& D, Alfabeta, Bandung.

Supartono. 2006. Pengembangan Perangkat Pembelajaran Matematika Realistik untuk Materi lingkaran di kelas VIII SMP Negeri 1 Bubulan Bojonegoro. Mathedu; Vol 1 No. 2 Juli 2006. PPS UNESA: Surabaya.

Suryanto. 2001. Pendidikan Matematik Realistik. Makalah tidak dipublikasikan pada Lokakarya Widyaiswara BPG se-Indonesia tanggal 27 Maret s.d. 9 April 2001 di PPPG Matematik Yogyakarta.

Zulkardi. 2005. Peningkatan Mutu Pendidikan Matematika Melalui Pembelajaran. Tersedia di http://www.pikiran-rakyat.comdiambilta nggal 11 Juli 2005.

Zulkardi. 2007. Arti PISA, TIMSS, dan UN bagi Guru Matematika. Makalah Seminar Nasional Pendidikan Matematika. PPS FKIP UNSRI Palembang, 4 September 2007

Zulkarnain. 2000. Pembelajaran Yang Dimulai Dengan Pemberian Soal Cerita Untuk Meningkatkan Hasil Belajar Matematika Siswa Kelas II SMAN 2 Pekanbaru. Laporan Penelitian. Pekanbaru: Lemlit UNRI. 